\title{
On the Question of the Possibility of Using the Elements of the Knowledge Management Methodology in Modern Historiographical Research (Based on the Studies of Political Education of the Red / Soviet Army Personnel in 1918 - 1991)
}

\author{
Elena Yu. Bobkova
}

\begin{abstract}
Samara Cossack Institute Food Industry and Business (Branch) of the Moscow State University of Technologies and Management Named after K.G. Razumovskiy (First Cossack University), 443031, Samara, Russia
\end{abstract}

\author{
Doi:10.5901/mjss.2015.v6n5s3p140
}

\begin{abstract}
In the article, the perspective directions of development of the system of knowledge management when carrying out historiographic researches on problems of political and patriotic education of the staff of the military personnel are considered. The vector of development of modern scientific methodology staticizes the need of synthesis of traditional methodological tools of historiographic researches with the methodology of systems of continuous improvement of processes based on the principles of 6 sigmas. A search for new models and methodological approaches to specific historiographic problems staticizes their consideration at the theoretic-methodological level taking into spatiotemporal account transformations. The categorial essence of a definition "political education" which lost relevance at the end of the XXI century gradually starts reviving in modern scientific researches. Now, despite the multidimensional use of this definition, it is signed for Post-Soviet scientific researches while during the Soviet period its synonymous values were more often used. At the end of XX - the first decade of the XXI century the definition "political education", in relation to modern educational processes was practically not used; it was succeeded by more volume category "patriotic education". Since 2014, the term "political education" starts being used actively in mass media, its application and scientific researches is observed.
\end{abstract}

Keywords: historiographic researches, knowledge management, methodology, process approach, scientific researches.

\section{Introduction}

The organizational and political changes of a vector of ideological development of our country, which are boldly reflected in all spheres of social development of Russia in the second decade of the XXI century, staticize need of modernization processes for the sphere of methodology of the historiographic researches affecting area of military history.

In particular, it concerns the sphere of accumulation and the analysis of historiographic knowledge in the field of formation and development of an ideological component of the educational process of the staff of Armed Forces.

The era of methodological pluralism in historiographic researches which began last century in a combination to structural changes of global information space, demands activation of search of new models and approaches to studying of history of historical science, both at the general theoretic-methodological level, and at the level of researches of specific historiographic problems.

One of the directions synthesis of traditional historiographic approaches in the field seems methodological tools of management of knowledge, to the so-called "knowledge-approach" which gained at the beginning of the XXI century distribution in economic to the sphere and approach to the continuous improvement developed methodology of 6 sigma from subject domain of quality management.

The purpose of this article: to consider the directions of the development of the system of management of knowledge based on process approach when carrying out historiographic researches on problems of political education of the military personnel.

For achievement of a goal, it is necessary to carry out previously the analysis of the categorical essence of a definition "political education" about Staff of Armed Forces of the country.

Relevance of studying of a problem of political education is also emphasized by researchers of military psychology, so a number of researchers consider that "military and professional, moral and policy components of a moral and psychological state are the leaders defining its contents, an orientation and level of functioning" (Korchemny P. A., 2008). Now for strengthening of positions in the army the solution of a question of strengthening of political education and education of the military personnel is inevitable. Political scientists at the end of the XX century noted that neutralization by military means of internal sources of danger demands or entering of essential amendments into the available 
mechanism of political socialization of military, or creations of own mechanism under problems of a concrete militarypolitical situation (Zhukov V. I., 1997).

Studying of a problem of political education in historical aspect devoted works and on military to pedagogics, so, for example, it is noted that "in the course of formation of the Workers' and Peasants' Red Army (WPRA) and the Workers' and Peasants' Red Fleet (WPRF) .... In military and pedagogical process the political education of the army personnel aimed first of all at formation of communistic consciousness of fighters and commanders, socially significant qualities of defenders of the socialist state started taking a special place." (Efremov O. Yu., 2008).

The military historian O. F. Suvenirov, considering a problem of military discipline and a law and order in army during the enter military period, through political education of staff tries to show how influence on staff for the purpose of their motivation to conscious performance of military duty on protection of the socialist Fatherland appeared methods of agitation and propaganda work (O. F. Suvenirov, 1976).

Further, in days of the Great Patriotic War and post-war time the content of education of the military personnel was defined as ideological and political, military, atheistic, moral, legal, esthetic and physical training (Anashkin O.A., 2004).

It should be noted that, despite a significant amount of scientific works in which the problem of political education of the military personnel is directly and indirectly considered, its structural and substantial analysis is practically not carried out by scientists. Moreover, only in V. Ya. Efremov's work it is noted that in the Soviet historical science by consideration of a problem of political education of the military personnel other definition "ideological and political education" which had "to a limit the contents politized internally" (Efremov V. Ya. was often used., 2007), and the studied definition appeared only during the Post-Soviet period.

Ideological and political education of the military personnel was one of the main directions of work with the staff of VS USSR. It was carried out in the following forms: " Marxist-Lenin training of officers by carrying out regular trainings in days of commander preparation, at universities of Marxism-Leninism, activation of independent preparation, weekly political occupations with soldiers and sergeants" (Smirnov G. I. and Yasakov A.I., 2002).

As a synonym of the studied definition in a number of works the term "political preparation", considered as system of actions for ideological and political education of the military personnel, workers and employees of the Soviet Army and the Navy meets. The term "political study" considered as system of actions for ideological and political education of the military personnel, workers and employees of the Soviet Army and the Navy", included in system of party and political work can be considered synonymous.

For carrying out the structural and semiotics, analysis of a definition "political education" of staff of the military personnel is obviously necessary to consider in details essence of this terminological phenomenon in existential borders, also including modern treatments of this term.

The analysis of modern terminological dictionaries on the military subject showed that this definition of them is absent, now it occurs only in pedagogical and political dictionaries.

Thus, it is possible to allocate a key component of this type of education - formation of political culture, i.e. a certain valuable and standard system of the service member.

It should be noted that with a staff of Armed Forces of the Russian Federation we do not find this type of education in modern works on problems of the organization and carrying out educational work. The modern military pedagogics allocates the following types of education of the army personnel: "state and patriotic, military, moral, legal, economic, esthetic, physical and ecological" (Efremov O. Yu., 2008). Proceeding from the substantial analysis of the term "political education" of the military personnel, it is possible to draw a conclusion that the closest to a definition "political education" according to the contents of this list is the term "state and patriotic education", considered as "rendering impact on the military personnel for formation and development of the personality possessing qualities of the patriotic citizen [...] capable actively to participate in strengthening and improvement of bases of the society prepared for successful performance of the tasks connected with ensuring defense and safety of the personality, society and state" (Efremov O.Yu., 2008).

It is possible to allocate the following basic conceptual elements of substantial essence of this term: formation of an active civic stand of the identity of the serviceman allowing it to fulfill national objectives effectively in peace and a wartime; accumulation of moral spirit of Armed Forces on the basis of heroic traditions of the people of Russia and Armed Forces; improvement of international education of the military personnel in the spirit of friendship of the people.

Thus, having analysed the substantial essence of the term "political education" of the military personnel and its synonyms used in the period of the USSR and having carried out the comparative analysis with categorical essence of this term in modern scientific literature, it is possible to make the following generalizing judgments.

Political education of the military personnel - concept the many-sided, having the purpose formation at staff of armed forces of complete valuable and standard system, with certain distinctive signs: fidelity to the state and a military 
duty, understanding of the foreign and domestic policy pursued by the state, identification of belonging to army as to social Institute and own identification as defender of the state. Patriotic education is part of the system of political education of the military personnel but does not replace it.

During the Soviet period, political education of the soldiers was an element of communistic education which main objective was formation at the service member of complete valuable and standard system of the defender of the socialist fatherland. In the Soviet historical science about the military personnel, a definition "political education" is practically not analyzed and rather seldom meets. Its synonyms are: "political preparation", "ideological and political education", "political study".

In Post-Soviet historical researches about the military personnel, the definition starts being used actively, also, as a synonym the terms "patriotic education", "ideological education" are used

Further, following the chosen logic of a statement of results of research, it is obviously necessary to consider influence of a vector of a multipara dismality of approaches and methodological pluralism in scientific researches on origin of processes of integration of methodological tools of management of management of knowledge and historiographic researches.

Formation of a common information space and development of information technologies caused qualitative changes in an information field of historical and historiographic researches. Principles of methodological pluralism (Bobkova E.Yu., 2014 and Magsumov T.A., 2014) in combination with expansion of the sources base thanks to virtualization of scientific space staticize need of synthesis of traditional historiographic approaches with methodological tools of management of knowledge (Bobkova E.Y. and Tushavin V.A. 2015). One of the actual problems during the work with historical and historiographic sources is their ranging; that is a comparison of sources on the degree of reliability of reflection of the studied area.

This task has complex character and has no rather well fulfilled methodological basis. In this case, great value acquires knowledge and practical experience of experts. At the same time, similar problems are rather successfully solved in management using tools and methods of management of quality (Tushavin V.A., 2014). It should be noted that having only defined requirements to historiographic sources, the researcher can analyze their qualitative characteristics (Tushavin V.A. and Bobkova E.Yu., 2015).

\section{Literature Review}

As it was already noted earlier, the category "political education of the military personnel" - concept difficult and manysided. A.V. Grinev gives the following treatment to political education - "education political - the process of systematic and purposeful impact on political consciousness and behavior [...] including forming of consciousness and consciousness [...]" (Grinev A.V.). In the Political Science Dictionary (Sanzharevsky I.I., 2010) we meet a few other treatment: "Education political - impact on political consciousness for the purpose of forming of the political culture adequate to interests of political elite". A.S. Voronin gives the following treatment "Education political purposeful activities for the education of political culture [...]. It is shown in a particular political position [...] which defines her views, the relations and actions [...]" (Voronin A.S. 2006)

As the problem of creation of system of organizational learning and knowledge management" (many researchers note Tushavin V.A., "now., 2014) in all spheres of social development purchases the increasing relevance, but in methodology of historiographic researches (in the conditions of dynamic fundamental transformations of the information space available to the researcher) this task becomes one of the backbone, allowing to verify processes of accumulation and the analysis of historiographic knowledge. Synthesis of methodological approaches to the solution of scientific tasks from different areas of researches demands forming of the accurate categorical device therefore, within the chosen logic of research it is of course necessary to designate essence of fundamental categorical units.

The explanatory notes of a knowledge management system in modern science are partially created therefore within the research we find possible use of the following, quite settled values of fundamental methodological definitions: "learning" - acquisition of knowledge, skills and "organizational learning" - the mechanism of forming of the accumulated knowledge of the organization. In the conditions of need of capitalization of scientific knowledge (Karavayeva A.S., 2010), specialists in the field of historiographic researches within the scientific and educational organizations can be carried to "kognitoriat", since to category of intellectual workers. In modern conditions, it is possible to formulate one of objectively existing requirements to the historiographer as follows - availability of system of knowledge and competencies for storage, processing's and transformations of a triad of "data-information-knowledge" (further - DIK triad). It should be noted that since the scientific and categorical device of this direction formed, proceeding from needs of the economic sphere of society, its use in the field of methodology of history of historical science demands a certain extrapolation. 
Therefore, for example, in a definition organizational learning under "organization" it is necessary to consider the scientific direction (school of sciences) of specific historiographic researches developed in the scientific (and/or) educational organization.

In the researches devoted to studying of forming of a knowledge management system, intangible assets of the organization are subdivided into three large classes: human, organizational and client capital. It should be noted that if the last two can find the reflection of balance (Tushavin V.A., 2014) the educational or scientific organization, the human capital in spite of the fact that exactly thanks to competencies of scientists also forms the organizational and client capitals, practically does not give in to the formalized control of the party. It should be noted that despite keen interest of researchers in the field of knowledge management, the task of transformation of human capital to the organizational and client is not solved even in the area of management in real production sector, not to mention scientific and educational sectors now.

\section{Methods and Materials}

The methodological basis of research was made by knowledge management methodology, ways of the historical, systems, logical analysis, scientific knowledge (comparison, the analysis, synthesis, analogy, generalization, induction, and deduction), a logical method and classification. For carrying out statistical analysis, the methodology of mathematical statistics, mathematical models and methods of the analysis with use of modern computer technologies was used.

\section{Results and Discussion}

Effective development of the scientific directions (schools of sciences) in the field of historiographic researches on problems of a military historiography, including - in the field of an increment of scientific knowledge in the field of political education of the army personnel, in the conditions of spasmodic development of an information field staticizes the need of synthesis of traditional methodological tools of historiographic researches with methodology of systems of continuous improvement of processes based on the principles of 6 sigma using tactics of gradual training, in the presence of methodological control, by means of joint operation on the basis of modern means of ICT.

In methodology of 6 sigma control of process is exercised by the "masters" (certified by methodologists) (Tushavin V.A., 2008), in historical science formally such institute is practically absent, but its role can be successfully implemented by scientific community of founders of profile schools of sciences and the directions in case of implementation of the corresponding methodology.

In this case forming and development of the scientific direction (school) of historiographic researches in organizational aspect will be based on the following principles: gradual presentation necessary for assimilation trained in information; optimum for the learning trained speed, availability at trainees of immediate feedback concerning correctness of learning.

Thus, the broad circulation of information-analytical systems and bibliographic databases of open access allows, due to use of a method of learning with a double loop (Tushavin V.A., 2011) to create a steady cognitive map at trainees of different level. Implementation of these tools in practice of development of the scientific directions (schools) of historiographic researches of the ideological directions of educational work in army it is quite difficult since, indifference from the classical scheme of functioning of business processes in the organization, the system of formalized developments of the historiographic scientific directions from methodological positions of knowledge management is in embryo.

It is represented that for forming of a model of the creation of knowledge within the development of the scientific directions of the history of historical science in researches of the ideological directions of educational work in the army. Use of Basic Elements of the Japanese concept of "ba" (Nonaka I., 2010) can be effective. Essence of a definition of ba in this case - the information platform which is concentrating resources of the scientific direction (school), turning on the body of the verified historiographic knowledge (assets of knowledge) and the available intellectual opportunities of the scientific direction (school) within creation of new historiographic knowledge.

In the classical ba model, there are four of its types causing the probability of possible transitions of knowledge and creating a model of knowledge of SECl.

Initial ba - is a basis for forming of knowledge (Bobkova E.Yu., 2015). In an aspect of the development of the scientific historiographic direction (school), it includes personal contact of the structure of the direction (school) which serves for transfer of implicit knowledge between participants within the scientific group. Scientific group, in this case, can be or communication: the founder of school - his doctoral candidates, graduate students, undergraduates, bachelors 
working on one historiographic task, or communication: the researcher - trainees, backbone elements, in this case, is a specific historiographic problem. The efficiency of transfer of implicit knowledge increases when using a method with arrangements (PMBOK® Guide, 2013), i.e. implementations of conditions of the interaction of members of the scientific group in real time.

The researcher (the founder of the direction) consciously in the course of creation and development of scientific group creates interacting oh it. In Eph a phase group work group work on different tasks (for example joins: carrying out the content analysis, forming of base of sources, development of criteria for aggregation of sources by means of search queries, etc.) in which individual mental models and skills by means of dialogues in real time turn into expressions and concepts groups available to all participants. Fixation of the results received in this phase on different material carriers characterizes the process of transformation of implicit knowledge in the explicit. End of this phase allows carrying out efficiency evaluation of work of the scientific group on formatted criteria. Effective strategy and transactions for development of scientific group have to increase labor productivity of group that in turn promotes achievement of goals (Bobkova E.Yu., 2015)

Virtual oh (a combination phase) integrates new explicit knowledge with the existing information that generates and systematizes the explicit knowledge of the scientific direction (school). Set of publications intermediate results in the different open sources available to the discussion to the scientific community can be the formatted characteristic of achievement of this phase. All documentation received by participants of the scientific historiographic group on this phase in the terminology of management of knowledge can be considered as a place of creation of new explicit knowledge, or the accumulated knowledge. The key function of this knowledge is the implementation of opportunity for the scientific direction to level delusions and methodological errors of last periods.

The phase practical oh (internalizations) promotes transformation of explicit knowledge in implicit by target training of participants of the scientific direction by means of their inclusion in a scientific paradigm, creating skills of use of standard methodological instruments of historiographic researches.

Use of spiral model of development of knowledge within functioning of the scientific direction (school) of historiographic researches of problems of political education of the military personnel shows that despite a significant role of the information technologies allowing to increase efficiency of research work of the historiographer application of classical technocratic behavior model at creation of a management system historiographic knowledge can be counterproductive since full automation of process by knowledge managements at the present stage of development of ICT is impossible.

\section{Conclusion}

Knowledge management, especially in the field of history of historical science, is difficult multidimensional process, its formation has to happen gradually, being based on the principles of project management allowing to consider creation organizational (in this case - scientific) assets within the researchers conducted by all members of the scientific direction. The modern dynamically developing processes of transformation of information public processes, involving cardinal changes not only in technical, but also in social and philosophical and methodological aspects of the organization and carrying out historiographic researches, especially in the field of an increment of historiographic knowledge of problems of an ideological component of educational process of staff of Armed Forces, emphasize relevance of scientific search for the effective methodological approaches corresponding to objectively existing realities of informatization and virtualization of society.

In this case, one of the key positions is occupied by the development of the system of knowledge management of the scientific direction (school). Synthesis of classical and modern methodological approaches not only allows to expand communications in the scientific community, starting, in turn, a spiral of the creation of the verified knowledge but also is the basis of all system.

In too time, it should be noted that the basis is not self-sufficient, and, for successful functioning of all system, presence of the architect of a knowledge management system - the person (group of persons) responsible for creation and accumulation of knowledge in the scientific direction is necessary. In most cases, it will be the good founder of the scientific direction (school of sciences) and/or his main followers

\section{References}

A Guide to the Project Management Body of Knowledge (2013): An American National Standart ANSI/PMI 99-001-2013, Project Management Institute, Inc. No. ANSI/PMI 99-001-2013. Fifth edition. Pennsylvania, USA: Project Management Institute, Inc. pp. 
618.

Cobi T 4.1. (2008) M: Audit and control of information systems. pp. 240.

Podmetina, D., Smirnova M., Vaatanen J. and Torkkeli M. (2009) Innovativeness and International Operations: Case of Russian R\&D Companies//International Journal of Innovation Management. Vol. 13. N 2. pp. 295-317.

Pritula, V.I. and Levchenko Z.M. (2013) System of mentoring: management of corporate knowledge and skills // Bulletin Vinnitsa Polytechnic Institute. № 3 (108). pp. 113-118.

Antokhina, Yu.A., Varzhapetyan F.G., Ovodenko A.A. and Semenova E.G. (2012) Methods and management tools quality of projects. SPb.: GUAP. pp. 303.

Big encyclopedic dictionary//Encyclopedias \& Dictionaries. Access mode: http://enc-dic.com/enc_big/Nauchenie-39717.html. (Date of the address: 03.01.2015)

Gladkov, L.A. and Gladkova N.V. (2013) Possibilities of knowledge management on the basis of hybrid intellectual methods//Open education. No. 6. pp. 60-64.

Karavayeva, A.V. (2011) Process of capitalization of knowledge in higher education institution as one of evaluation methods of the cost of a human capital//National interests: priorities and safety. No. 30. pp. 39-45.

Concept ba: organizational mechanism of creation of knowledge (2010). Nonaka, N. Konno//Knowledge management: Anthology. 2nd prod. Per with English Under the editorship of T.E. Andreyeva, T.Yu. Gutnikova; The Higher school of management of St.Petersburg State University. SPb: Publishing house "Higher school of management". pp. 275-292.

Palagin, A.V. (2014) Transdistsiplinarnost, information science and development of modern civilization// Bulletin of the National Academy of Sciences of Ukraine. № 7. pp. 25-33.

Putin, V.V. (2014) Performance at a meeting of Council for the International relations//the Messenger of the Russian nation. T. 4. No. 4 (36). pp. 8-10.

Putin V.V. (2014) Message to Federal Assembly of the Russian Federation//Messenger of the Russian nation. T. 1. No. 1 (33). pp. 8-2.

Putin, V.V. (2012) Russia and the changing world//the Messenger of the Russian nation. T. 2-3. No. 22-23. pp. $13-23$.

Tushavin, V.A. (2014) Kaydzen and Scrum projects as the instrument of organizational learning in the IT company / NIU ITMO scientific magazine. Economy and Ecological Management Series, No. 1. pp. 80.

Tushavin, V.A. (2008) Practical use of project approach for knowledge management in the modern IT company//Problem of Economy. pp. 109-111.

Tushavin, V.A. (2011) Statisticheskaya an assessment of input parameters of processes of technical support and incident management//Equipment and Technology, No. 4. pp.44-48.

Bobkova, E. Y. and Tushavin V.A. (2015) Qualimetric Approach to Quality Assessment of Historiographic Sources (Through the Example of Historiographic Researches, Dedicate to Problems of Political Education of Personnel for the Red (Soviet) Army) // The Social Sciences. №. 10 (3). pp. 249-252.

Bobkova, E.Yu. (2015) Use of the process approach to knowledge management when carrying out historiographic researches on problems of political education of the staff of Red (Soviet) Army//Economy and management of management systems. No. 1(15). pp. 23-3.

Information Technology in chronotopic kliodeskripnom content analysis historiographical sources // Applied research: a multidisciplinary approach: proceedings of the international scientific conference on 11-12 December 1014. Samara State Aerospace University, 2014. pp. $109-110$

Korchemny, P.A. (2008) Military Psychology: methodology, theory, and practice. M.: Voyenizdat. pp. 280 URL: http://www.gumer.info/ bibliotek_Buks/Psihol/abdur/25.php

General and applied political science. / Under the editorship of V. I. Zhukov, B. I. Krasnov. M.: MGUSU, 1997. pp. 992.

Military pedagogics: the textbook / under the editorship of O.Yu. Efremov (2008). SPb.: St. Petersburg. pp. 640.

O.F souvenirs. Communist party — the organizer of political education of Red Army and Fleet. 1921-1928 M.

Anashkin, O.A. (2004)Sovershenstvovaniye of the content of the education of the military personnel of Armed Forces of the Russian Federation: yew. On jays. uch.step. k.ped. sciences. M. pp. 252. URL: http://dlib.rsl.ru/rsl01002000000/rsl01002629000/rsl010 02629269/rsl01002629269.pd

Efremov, V.Ya. (2007) Activities of power structures for strengthening of moral spirit of Armed forces of the Soviet state (1918 - 1991): historiographic research: yew. on soisk. Wuchang. step.d-ra istor.nauk. - Samara. pp. 620. URL: http://dlib .rsl.ru/rsl01004000000 /rsl01004107000/rsl01004107728/rsl01004107728.pdf

Smirnov, G.I. and Yasakov A.I. (2002) Istoriya of the 50th Rocket Army. I. Creation and formation (1959-1964). Smolensk: Smolensk regional department of AVN Russian Federation. URL: http://rvsn.ruzhany.info/50ra_t1_p8.html

Bobkova, E.Yu. (2014) Reflection of Party and State Concept of Political Indoctrination of the Red Army Contingent in the Works of the Soviet State Military Leadership // Middle-East Journal of Scientific Research, № 19 (4). pp. 497- 500. DOI: 10.5829/idosi.mejsr.2014.19.4.21002.

Magsumov, T.A. (2014) Main approaches to the study of historical and educational process // Bylye Gody. Volume 34, Issue 4, 1 December 2014, pp. 720-726.

Bobkova, E.Yu. (2015) Use of the process approach to knowledge management when carrying out historiographic researches on problems of political education of the staff of Red (Soviet) army//Economy and management of management systems. T. 1. No. 15. pp. 23-31.

Tushavin, V. (2014) Axiomatically design projects as a tool to improve the quality // Modern trends of strategic development of the 
enterprises: Proceedings of the International scientific and practical conference. Yelm, WA, USA.: Science Book Publishing House. P. 61-67.

Tushavin, V.A. and Bobkova E.Yu. (2015) Metodik of a qualimetrical assessment of characteristics of quality of historiographic sources//Modern science: actual problems of the theory and practice. Natural and Technical Science Series, No. 01-02 2015. pp. 11-16.

Grinev, A.V. (2015) The short terminological dictionary on political discipline science.URL: http://www.politike.ru/dictionary/867/word/ vospitanie-politicheskoe.

Political science: dictionary reference / Sost. Professional floor of Sciences Sanzharevsky I.I., 2010.URL: http://enc-dic.com/polytology/ Vospitanie-2903.

Voronin, A.S. The dictionary of terms on the general and social pedagogics,2006. URL: http://voluntary.ru/dictionary/898/word/ vospitanie. 